\begin{tabular}{c} 
Volume and Issues Obtainable at Center for Sustainability Research and Consultancy \\
Responsible Education, Learning and Teaching in Emerging Economies \\
ISSN: 2708-4310 \& (E): 2708-4183 \\
Volume 3: No.1, June 2021 \\
CSRᄃ \\
Journal homepage: $\underline{\text { www.publishing.globalcsrc.org/relate }}$ \\
\hline
\end{tabular}

\title{
Study of Conflict Management Styles of University Teachers at Post-Graduate Level: The Impact of Gender and Marital Status
}

Umm e Habiba, Punjab School Education Department, Lahore, Pakistan

*Tahira Batool, Lahore College for Women University, Lahore, Pakistan

Sayeda Ayesha, Punjab School Education Department, Lahore, Pakistan

*Corresponding author's email address: batooltahra@gmail.com

\begin{tabular}{l}
\hline ARTICLE DETAILS \\
\hline History \\
Revised format: May 2021 \\
Available Online: Jun 2021 \\
\hline Keywords \\
Conflict Management \\
Styles, Competition, \\
Collaboration, Avoidance, \\
Accommodation.
\end{tabular}

JEL Classification

A2, A29
ABSTRACT

Purpose: The objective of the study was to identify the conflict management styles of Pakistani teachers teaching at the post-graduate level. The study also aimed to investigate differences, if any, between male and female as well as married and un-married teachers regarding the use of conflict management styles.

Design/Methodology/Approach: The sample of the study consisted of 300 male and female teachers from five public universities of Lahore district.

Findings: We found that collaborating conflict management style is used most frequently by teachers who participated in this study. In this regard, the majority of teachers were found to use the avoiding technique "keep yourself away from conflict" to resolve the conflict. There was a significant difference between married and un-married teachers regarding their competing and compromising conflict management styles. However, no significant difference was found between male and female teachers regarding their conflict management styles.

Implications/Originality/Value: More research may be conducted in academic institutions regarding conflict management skills among teachers. The study suggested that educational institutions may also formulate their teams of expert teachers, which may work effectively during the times of conflicts or crisis.

(C) 2021 The authors, under a Creative Commons AttributionNonCommercial 4.0

\footnotetext{
Recommended citation: Habiba, U. Batool, T. \& Ayesha, S. (2021). The conflict management styles of university teachers at the post-graduate level: The impact of gender and marital status. Responsible Education, Learning and Teaching in Emerging Economies, 7 (2) 47-55.
}

\section{Introduction}

There are various conflicts in every organization, departments and institutions and these conflicts become cause of creating tension, anxiety and unpleasant experiences among professionals, 
employees and workers (Schmuck \& Runkel, 1985). In addition, Fleetwood (1984) stated, that it is essential for teachers to know why they are often central to community controversies. Furthermore, Owens (2004) also argued that the application of conflict management techniques in any profession is very useful due to its productive, creative and useful outcome. So, teachers may need to know ways of keeping conflict to a minimum level and of solving problems caused by a conflict before it becomes a major obstacle to their work. Because, when frustration increases, it develops a situation of conflict in educational institutions as a natural part of life. Conflicts may exist where incompatible activities occur and these may be among individuals, groups and whole society and culture. Conflicts between two or more persons or social units are called interpersonal or intergroup conflicts. Most conflicts are interpersonal and intergroup in nature (Silver, 1983).

Most of the research on conflict management has been conducted in traditional organizations but this does not mean that educational institutions are free of conflicts. Conflicts are more likely to occur in the institutions of higher education because of the encouragement of academic freedom and uncontrolled thinking. Conflict can occur between students and faculty, faculty and faculty, faculty and administrators and students and students (Safarali \& Salleh, 2013; Gaffar, 2005; Nichal, 2013).

Educational institutions, similar to other organizations, need to develop a shared vision of its people including what they are striving to achieve clear objectives for both teachers and students. That is why there is a need for finding ways of recognizing and resolving conflicts between teachers and students. Ndofirepi and Makaye (2012) pointed out those conflicts which exist mostly in schools between heads and teachers over unequal distribution/allocation of resources and gossips. Furthermore, most teachers are not satisfied with those methods and techniques which are using for conflict resolution by the heads. In result, teachers prefer District Education Officers (D.E.Os) to work as mediators while resolving conflicts with their school heads. Okotoni and Okotoni (2003) argue that, in such situations, an effective use of relevant strategies by school administrators cannot be ignored.

A study of Masila (2012) found few principals of primary and secondary schools of South Africa were prepared adequately for conflict management. They usually misunderstood the role of conflict and immediately avoided or halted conflicting situations. Thus, there is a need for effective strategies to deal with conflicts within educational institutions. Strategies adopted for this purpose may vary according to the conflict, institutions and parties involved. Evidence provided in the study of Graham (2009) about the use of conflict management strategies that managers can use different styles when attempting to resolve conflicts, however, it is important to note that there is no single style that fits in all situations. Overall, an appropriate conflict management strategy may depend on the type of conflict and the seriousness of the issue. Because of the importance and need for conflict management in an educational institution, this study aims to find out various conflict management strategies used by teachers in the Pakistani context.

Owens (2004) observed the people can solve many problems and issues in order to improve the institutional functioning through conflict management. He also says, often when conflict occurs win-lose approach might be avoided because it is the least productive approach in which one person must have to get success and the other fails. On the other hand, if we use a win-win approach, it may be more fruitful and productive because both persons get success. Meyers (2003); Booth (2001) and Akintayo (2012) suggested that teachers are usually not prepared to handle classroom conflicts effectively which may be disturbing, distressing and disruptive for students and the learning environment. Schlesinger et al. (1983) stated, bargaining and forcing, smoothing and avoidance, and confrontation and problem solving are the modes of conflict 
resolution. On the other hand, Peer mediation is also one of the strategies used to resolve a conflict. In this process, a group of teachers may be selected as peer mediators (Silver, 1983).

Keneth Thomas (2006) presented five conflict management styles competing, avoiding, accommodation, compromising and collaborating. Figure 1 shows the relationship between these five styles of conflict management along with assertiveness and cooperativeness.

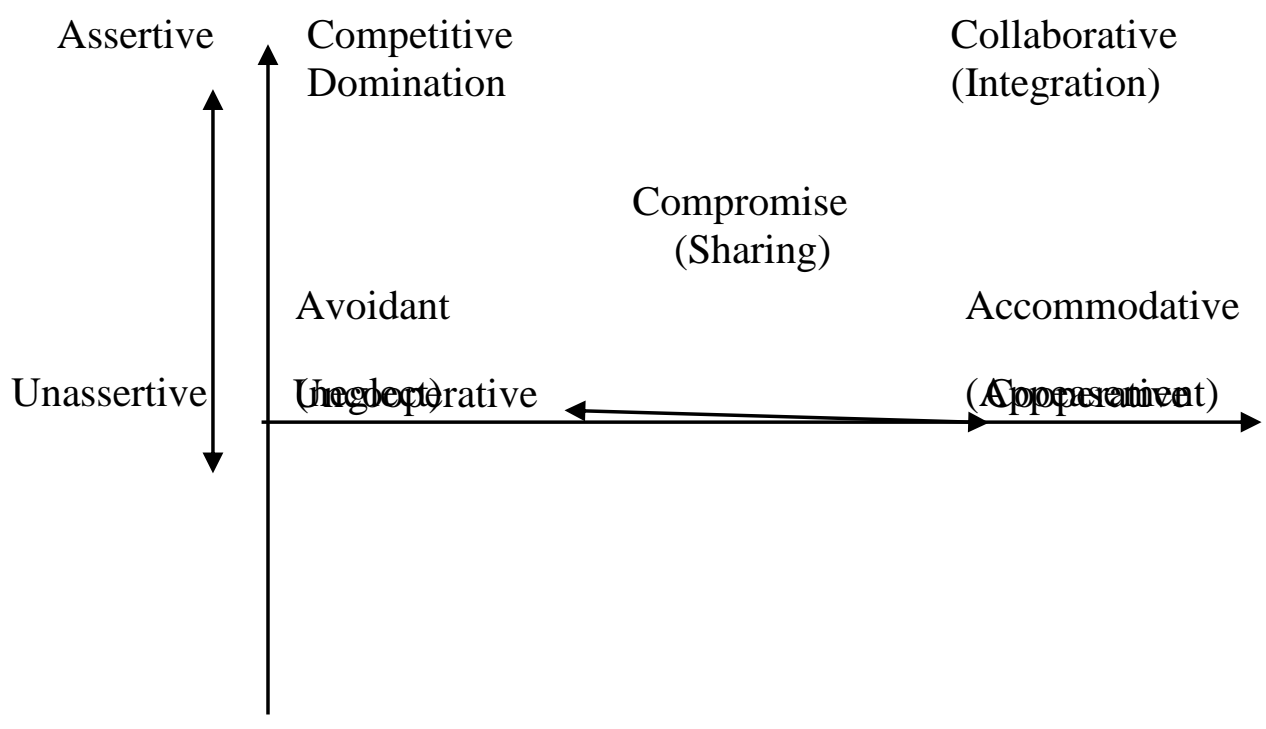

Fig 1: Keneth Thomas (2006) five conflict management styles

These five styles have been explained by Kenneth Thomas (2006) and Khanaki and Hassanzadeh (2010) in the following way. Avoiding (Unassertive and uncooperative) implies that an person neglects conflict or denies its existence. In this mode, one prefers to delay conflict or put it off until later. Avoidance may be used when an issue is trivial or other important issues are more pressing. It may also be workable when people need to cool down temporarily and wish to gain a clear perspective of the situation. In accommodating (Unassertive and cooperative) strategies a person usually overlooks one own desires to satisfy those of others. In other words, it is a form of selfless generosity in which one yields to others' wishes and would not prefer to do anything against others' expectations.

Compromising (Moderately assertive and moderately cooperative)strategies emerge when an person seek mutually acceptable solution for the parties involved in a conflict. This is a kind of solution which ideally satisfies the wishes of both persons/parties in the conflict. This strategy involves a consideration and respect for each other's desires as well. In this way, it is likely that some concerns of both persons may be neglected in the process of exchanging concessions and finding a middle-ground position. Compromise may be used for temporary settlements of complex issues or for arriving at expedient solutions when the time is limited.

In comparison, competing for (Assertive and uncooperative) strategies involve a person seeking his/her own desires, at the expense of others' desires, by using all appropriate/available power to win the position. In such strategies, a person does not sacrifice his/her own wishes to address the concerns of others. Therefore, an authoritative command may be used to find a solution of the conflict when a quick and decisive action becomes necessary.

Collaborating (Assertive and cooperative) strategies bring forward a person's pursuits for addressing all concerns of both parties in a conflict. This aims at finding a solution which satisfies both parties completely. In the case of collaboration, it is necessary to find those alternatives which are acceptable to all parties. Collaboration-based problem solving is preferred over other strategies when a mediator aims to gain a true conflict resolution, if the time and cost 
permit and the parties are willing to be both assertive and collaborative (Khanaki \& Hassanzadeh, 2010; Ikoya \& Akinseinde, 2009).

Chusmir and Mills (1989) indicate, as male and female teachers occupy different roles at work and at home,that both men and women adopt different conflict resolution behaviours in each role. However, Hendel, Fish and Galon (2005) investigated that compromising conflict management styles are used more frequently by the head nurses of different general hospitals in Israel. In particular institutions, principals and teachers are expected to deal with conflict situations not only on a daily basis, but frequently on an hourly basis. Conflicts are unavoidable, particularly in a scholarly setting thus, it is necessary for teachers to be able to recognize conflicts in order to understand their constructive as well as destructive potential. They learn how to manage conflicts, and how to apply conflict management strategies in a practical way.

This study was designed to investigate and analyzed conflict management styles used by teachers at postgraduate level while resolving conflicts with their peers and students. Knowing the conflict management styles of the members of an organization may play an important role in its smooth working and growth because these skills are important for individuals to work effectively at any level within the organization. To achieve this aim, the peaceful environment of an institution is necessary. An educational setting is considered to be a better place in which teachers and students may be expected to show and practice good moral behaviour. The students of post graduate level played a significant role in the progress of any country and in resolving the moral vices from society. Learning to deal with conflict is a life skill, which is also a need for teachers (Sidra \& Ayesha, 2006).Some types of conflicts demand new solutions and, therefore, enhance the creativity of people in an organization. To run an institution in a proper way, it seems necessary for the teachers to know various styles of conflict management so that they may handle conflicts in their organizations properly (Hoy \& Miskel, 2001; Lynette, Wilson, Jeni, 2006). Filley (1978) offerd problem-solving methods as an alternative to power-oriented approach for conflict management in the universities.

The main objective of the study was to find various types of conflict management styles which are adopted by the teachers at post graduate level in Pakistan. In this regard, the study also explored which style of conflict management is used most frequently by these teachers. In addition, it aimed to identify conflict avoidance techniques used by the participants of this study. Finally, we also looked into any gender differences among the participants in relation to their conflict management styles.

In line with the objectives of this study, we focused on the following research questions.

1. Which conflict management styles are used by a sample of Pakistani teachers at post graduate level?

2. Which style of conflict management is used more frequently by these teachers?

3. Which conflict avoidance techniques are used by these teachers?

4. Are there any differences between male and female participants in relation to their conflict management styles?

5. Are there any differences between married and un-married teachers regarding their conflict management styles?

\section{Methodology}

This research was quantitative in nature and survey by method

\section{Sample}

300 Male and female teachers from five universities situated in Lahore was taken as a research sample. 


\section{Sampling Technique}

Firstly, five universities were selected by simple random sampling from district Lahore. Furthermore, convenient sampling technique was used to include 300 teachers teaching at postgraduate level from these institutions.

\section{Instrument}

Five point Likert scale (Questionnaire) was based on the standardized instrument of ThomasKillmann (2006). The questionnaire included 33 items related to conflict management styles: competing (6 items), collaborating ( 9 items), avoiding (7 items), collaborating (5 items) and compromising (6 items). Teachers responded to each statement on a five-point Likert scale ranging from 1 (strongly disagree) to 5 (strongly agree).

\section{Data Collection Procedure}

Researchers themselves distributed questionnaires among participants. Completed questionnaires were used for the detailed analysis. First of all, respondents were informed about the purpose of the study, to examine how teachers manage their conflicts in different universities at post graduate level according to their educational level and designation, and then the questionnaire was administered on them.

\section{Data Analysis}

Participants' responses against each item were calculated, using frequency and percentage measures, to ascertain frequently used styles and techniques for conflict management and conflict avoidance. In addition, t-test analysis was used to find any gender differences among participants in relation to their use of conflict management styles.

\section{Findings of the study}

Following are the findings of the study based on its data.

Research question 1: Which style of conflict management is used more frequently by these teachers?

Table 1

Conflict management styles frequently used by teachers

\begin{tabular}{lll}
\hline Styles & $F$ & $\%$ \\
\hline Collaborating & 91 & 29 \\
Competing & 77 & 26 \\
Compromising & 74 & 25 \\
Accommodating & 50 & 17 \\
Avoiding & 8 & 3 \\
\hline
\end{tabular}

Table 4.2 shows that conflict management styles which are used most frequently by the teachers at post graduate level are collaborating (29\%), competing (26\%), and compromising (25\%). The least used one is avoiding (3\%). Other styles lie between the collaborating and avoiding. Research question 2: Which conflict avoidance techniques are used by these teachers?

Table 2

Frequency and percentage of teachers who use conflict avoidance techniques

\begin{tabular}{|c|c|c|c|}
\hline Sr\# & Avoidance techniques used by the teachers & $\mathrm{F}$ & $\%$ \\
\hline 1 & I believe that others can solve the problem more effectively. & 116 & 38 \\
\hline 2 & Keep me away from conflict. & 208 & 69 \\
\hline 3 & Avoid discussing the issues with others. & 118 & 39 \\
\hline 4 & Withdraw from controversy. & 198 & 66 \\
\hline 5 & Be silent when any dispute arises & 153 & 51 \\
\hline 6 & Avoid expressing my feelings in public. & 141 & 47 \\
\hline
\end{tabular}


$7 \quad$ Avoid sharing anything with others.

Majority of teachers (69\%) agreed to use avoiding technique "keep yourself away from conflict" and second frequently used technique (66\%) is "withdraw from controversy". Only $(29 \%)$ the number of teachers agreed that they use "avoid toshare anything with others" technique for conflict management.

Research question 3: Are there any differences between male and female participants in relation to their conflict management styles?

Table 3

Comparison of Male and Female Teachers Regarding Conflict Management Styles

\begin{tabular}{|c|c|c|c|c|c|c|c|}
\hline \multirow[t]{2}{*}{ Conflict Management styles } & \multicolumn{2}{|c|}{ Male } & \multicolumn{2}{|c|}{ Female } & \multirow[t]{2}{*}{$\mathrm{t}(298)$} & \multirow[t]{2}{*}{$\mathrm{P}$} & \multirow[t]{2}{*}{ Cohen'd } \\
\hline & $\mathrm{M}$ & $\mathrm{SD}$ & $\mathrm{M}$ & SD & & & \\
\hline Competing & 4.06 & .50 & 4.07 & .44 & 0.22 & .82 & 0.02 \\
\hline Collaborating & 4.04 & .55 & 4.15 & .42 & 1.85 & .066 & 0.22 \\
\hline Avoiding & 3.24 & .93 & 3.34 & .72 & 1.07 & .29 & 0.12 \\
\hline Accommodating & 3.72 & .65 & 3.86 & .60 & 1.87 & .063 & 0.22 \\
\hline Compromising & 4.00 & .66 & 4.00 & .60 & 0.06 & .95 & 0.00 \\
\hline
\end{tabular}

The value of t-test shows that there is no significant difference $(P>.05)$ between male and female teachers regarding conflict management styles i.e. competing, collaborating, avoiding, accommodating and compromising.

The effect size of each conflict management style was calculated using Cohen's formula. The values of Cohen'd fall between 0 to 0.22 . These values indicate that effect size is small.

Research question 4: Are there any differences between married and un-married teachers regarding their conflict management styles?

Table 4

Comparison of Un-married and Married Teachers Regarding Conflict Management Styles

\begin{tabular}{|c|c|c|c|c|c|c|c|}
\hline \multirow[t]{2}{*}{ Conflict Management styles } & \multicolumn{2}{|c|}{ Un-married } & \multicolumn{2}{|c|}{ Married } & \multirow[t]{2}{*}{$\mathrm{t}(298$} & \multirow[t]{2}{*}{$\mathrm{P}$} & \multirow[t]{2}{*}{ Cohen'd) } \\
\hline & $\mathrm{M}$ & $\mathrm{SD}$ & $\mathrm{M}$ & SD & & & \\
\hline Competing & 3.96 & .44 & 4.11 & .48 & -2.71 & .01 & 0.32 \\
\hline Collaborating & 4.03 & .47 & 4.12 & .50 & -1.60 & .11 & 0.18 \\
\hline Avoiding & 3.35 & .60 & 3.26 & .92 & .83 & .41 & 0.11 \\
\hline Accommodating & 3.79 & .61 & 3.80 & .64 & -.06 & .96 & 0.01 \\
\hline Compromising & 3.90 & .64 & 4.06 & .62 & -2.04 & .04 & 0.25 \\
\hline
\end{tabular}

The value of t-test shows that there is a significant difference $(P<.05)$ between married and unmarried regarding competing and compromising conflict management style. Married teachers usecompeting style for resolving conflict more as compared to un-married teachers. Married teachers are more compromising as compared to un-married teachers. Thevalue of t-test shows that there is no significant difference $(P>05)$ between married and un-married regarding collaborating, avoiding and accommodating conflict management styles.

\section{Discussion}

The study investigated the use of five conflict management stylescollaborating, competing, avoiding and accommodating by teachers. We found that collaborating conflict management style is used more frequently by university teachers as compared to other styles. Our study supports the findings of Alzwareh and Khasawneh (2011) in which integrating (collaborating) conflict management style was found to be practised frequently by Jordanian managers of manufacturing industry, whereas they adopted the compromising approach moderately as their secondary style. In addition, other studies also reported that problem-solving approaches are often preferred over 
power-oriented solutions while resolving the conflicts because they help to promote cooperation and participation among all parties to the conflict in an organization (Filley, 2002; Hatfield \& Hatfield, 2010). Majority of teachers participated in our study preferred to use avoiding technique "keep yourself away from conflict". Similarly, the study of Khanaki and Hassanzadeh (2010) revealed that both novice and experienced engineers of Irani teachers are frequently using collaborating, accommodating, and compromising techniques for conflict resolution. In the same way, the findings of Kaseh's (2014) study in Serbia found that collaborating was the most dominant style followed by competing, whereas avoiding was the least dominant style followed by compromising.

Further, Brewer,Mitchell and Weber (2002) reported that males prefer dominating conflict management style; on the other hand, females prefer avoiding conflict management style. Sontor and Vokic (2009) also showed similar results in which female employees used significantly more accommodating and compromising conflict handling styles as compared to men. However, there were no significant differences between men and women in using avoiding, competing and collaborating conflict resolution strategies. This study revealed significant differences between married and un-married teachers regarding the use of competing and compromising conflict management styles.We found that married teachers use more competing and compromising strategies for conflict resolution as compared to un-married teachers. In the same way, Sontor and Vokic (2009) found a significant difference between married and unmarried people in relation to their conflict management styles. They found that married people (employees) use more accommodating conflict handling styles than unmarried ones. In our study, however, no significant difference was found between married and un-married regarding the use of collaborating, avoiding, and accommodating conflict management styles. Feedback and Students Engagement also have positive effect on students achievements and attitudes of both male and female students (Batool, \& Akhter, 2019; Batool \& Akhtar, 2020; Batool, Akhter, \& Kalsoom, 2020).

\section{Conclusions and Recommendations}

The finding of the study revealed that a sample of Pakistani teachers use similar conflict management styles. For them, the most frequent conflict handling style is collaborating, followed by competing, compromising, accommodating and avoiding. Based on the findings, it may be better for teachers to avoid competitive approach while dealing with conflicts. The institutions may conduct workshops/seminars for the awareness of teachers about conflict management styles. More research may also be conducted in academic institutions regarding the measures of conflict management used by teachers at post graduate level. It is suggested to equip academic institutions with a team of expert teachers who know what to do during the times of conflict. This study relied on teachers' own perceptions about their conflict management styles; therefore, another study might be conducted to investigate their conflict management styles by using others' judgments about them. The study has investigated the use of a limited range of conflict management styles. In this regard, a qualitative study may be conducted to get in-depth and detailed views of teachers and professionals to find out other possible conflict management styles useful for academic institutions. If conflicts are managed it may have good effect on students teaching and learning. Parental involvement and feedback also impact positively on students achievements (Batool, Noureen, \& Ayuob, 2019; Batool, 2020: Batool, \& Raiz, 2020).

\section{References}

Akintayo, D. I. (2012). Influence of management styles of conflict resolution effectiveness in Work organizations in south-western Nigeria. International journal of Human Resource Studies, 2(4).

Brewer, N., Mitchell, P.,\& Weber, N. (2002). Gender role, organizational status, and Conflict 
management styles. The InternationalJjournal of Conflict Management, 13(1), 78-94.

Booth, Z. R. (2001). Relationships among conflict, conflict management, job satisfaction, intent to stay, and turnover of professional nurses in Thailand. Nursing \& Health Sciences, 2(1), 9-16.

Batool, T., Noureen, G., \& Ayuob, Z. (2019). Relating Learner Empowerment with Learner Self-Regulation Learning in Higher Education. Review of Economics and Development Studies, 5(4), 755-766.

Batool, T. Akhtar S. (2020). Investigating Cognitive Engagement of Eighth Graders' in Mathematics Classrooms.Global Social Sciences Review 5 (1), 322-331

Batool, T. (2020). Feedback Impact in High, Average and Low Achievers' Mathematics Engagement in High Schools' Classrooms. Review of Economics and Development Studies, Vol. 6 (1), 167-178.

Batool, T. \& Raiz, J., (2020). Exploring Parents Involvement in University Students Education. Journal of Business and Social Review in Emerging Economies, 6(1), 187-196. DOI: 10.26710/jbsee.v6i1.1037.

Batool, T., \& Akhter, M. (2019). Feedback effect on secondary school students' achievement ion Mathematics. Global Social Sciences Review, 4 (3), 123-134.

Batool, T., Akhter, S., \& Kalsoom, T. (2020). Exploring Gender differences in attitude towards Mathematics at Secondary Level in Pakistan. Journal of Business and Social Review in Emerging Economies, 6(2), 587-596.

Chusmir, H. L., \&Mills, J. (1989). Gender differences in conflict resolution styles of managers: At work and at home. The International Journal of Conflict Management, 20(3-4), 149163.

Fleetwood, L. K. (1987).Conflict management styles and strategies of educational Manager. Retrieved December from http://www.udeledu/communic- ation /web/thesis files /fleetwoodthesis.pdf.

Filley, C. A. (1978). Some Normative Issues in Conflict Management. California Management Review, 21(2), 61-66.

Ghaffar, A. (2005). Conflict in schools: its causes and management strategies. Journal of Managerial Sciences, 3(02), 212-227.

Graham, S. (2009). The effects of conflict management styles on job satisfaction in rural healthcare setting. Economics and Business Journal: Inquiries \&Prespectives, 2(1), 71-85.

Hoy, K.W., \&Miskel, G. C. (2001). Educational administration, Theory, Research \& Practice. New York: McGraw-Hill International.

Hatfield, W. D.,\& Hatfield, D. J. (1995). Relationships among Conflict Management Styles, Levels of Conflict, and Reactions to Work. The Journal of Social Psychology, 135(6).

Hendel, Fish., \&Galon. (2005). Leadership style and choice of strategy in conflict management in Israili nurse managers in general hospitals. Journal of Nursing Management, 13, 137146.

Ikoya, O.P., \&Akinseinde, I. S. (2009). Variability patterns in conflict management strategies among school administrators of secondary school in Nigeria. J SocSci, 20(3), 223-230.

Khanaki, H., \&Hassanzadeh, N. (2010).Conflict management styles: The Iranian general preference compared to the Swedish. International Journal of Innovation, Management and Technology, 1(4), 419-426.

Kaseh, E. F.O. (2014). Gender effect on the styles of managing interpersonal conflicts: An exploratory study on the academic staff of Stire University. J. Basic, Appl. Sci. Res, 4(5), 191-203.

Alzwareh, A., \&Khasawneh, S. (2011). Conflict management strategies adopted by Jordanian managers based on Employees' perceptions: the case for the manufacturing industry.Interdisciplinary Journal of Contemporary Research in Business, 3(7), 147-166.

Lynette, Wilson.,\&Jeni. (2006).The Impact of Perceptions on Conflict Management. 
Educational Research Quarterly, 29(4),3-15.

Masila, V. (2012). Conflict management and school leadership. J Communication, 3(1), 25-34.

Meyers, A. S. (2003). Strategies to Prevent and Reduce Conflict in College Classrooms. College Teaching, 51(3), 94-98.

Nischal, S. (2013). Exploring conflict management mechanism and the relationship between demographics and conflict handling styles in in private sector commercial bank. Pacific Business Review International, 6(1), 1-14.

Ndofirepi, P.A., \&Makaye, J. (2012). Conflict resolution between heads and teachers: the case of four schools in Masvingo Zimbabwe. Greener Journal of Educational Research, 2(4), 105-110.

Owens, G.R. (2004). Organizational behavior in education. (8 ${ }^{\text {th }}$ ed.).New York: Pearson Education, Inc.

Okotoni, O., \&Okotoni, A. (2003). Conflict management in secondary schools in Osun state, Nigeria. Nordic Journal of African studies, 12(1), 23-38.

Sidra, M., \& Ayesha, M. (2006). A study of conflict management styles of teachers \& students at secondary school level. Unpublished Master's Thesis, University of Punjab, Lahore, Pakistan.

Silver, P. (1983). Educational administration, theoretical perspectives on practice \& research. New York: Harper \& Row Publishers.

Schmuck, A. R., \&Runkel, J. P. (1985). The handbook of organization development in school. ( $3^{\text {rd }}$ ed.). California: Mayfield Publishing Company.

Schlesinger, A. L., Eccles, G. R.,\&Gabarro, J.J. (1983). Managing behaviour in organizations. New York: McGraw-Hill International.

Sontor, S.,\&Vokic, N. P. (2009). Conflict management styles in Croatian enterprisesRelationship between individual characteristics and conflict handling styles. Working paper series, 05-09.

Safarali, K., \&Salleh, J. M. (2013). An analysis of interpersonal conflict management styles practised by academic administrators at Islamic higher education institution, Malasia. Wcike-Journal of Integration Knowledge, 2289-5973. Retrieved from, www.worldconferences.net.

Thomas, W. K. (2006). Conflict styles of men and women at six organization levels. International Journal of Conflict Management, 19, (2), 148 - 166 